\title{
PROTECTIONISM SOURCES OF TRADE DISPUTES WITHIN INTERNATIONAL ECONOMIC RELATIONS
}

\author{
Yatsenko Olha ${ }^{1}$, Stašys Rimantas ${ }^{2}$, Tsygankova Tetiana ${ }^{3}$, Reznikova Nataliia ${ }^{4}$, \\ Uskova Domenika ${ }^{5}$ \\ 1. Dr, Prof. Kyiv National Economic University Named After Vadym Hetman. Peremohy Ave. 54/1. 03680, Kyiv, \\ Ukraine. Phone number +380679529916. E-mail: yacenkoolgakneu@gmail.com \\ ${ }^{2}$ Dr, Prof., Klaipeda University, S. Neries St. 5 - 101, Klaipeda, Lithuania E-mail: rimantas.stasys@ku.lt \\ ${ }^{3}$ Dr, Prof. Kyiv National Economic University Named After Vadym Hetman. Peremohy Ave. 54/1. 03680, Kyiv, \\ Ukraine. E-mail: tmtsygankova@gmail.com \\ ${ }^{4}$ Dr, Prof., Institute of International Relations of Taras Shevchenko National University of Kyiv, Yurii Illenko Street, \\ 36/1, 04119, Kyiv, Ukraine.E-mail:r_nv@ukr.net \\ ${ }^{5}$ Master, Kyiv National Economic University Named After Vadym Hetman. Peremohy Ave. 54/1. 03680, Kyiv, \\ Ukraine. Tel. +380939378646. E-mail: dominika_us@hotmail.com
}

Received 3010 2020; Accepted 17122020

\begin{abstract}
Peculiarities of modern intercountry trade disputes and their subject-object characteristics, protectionist methods due to the COVID-19 pandemic have been studied in the article. The purpose of the article is to study the features and tools for the implementation of modern interstate trade disputes in the context of strengthening protectionist policies and the spread of the COVID-19 crisis. The research methodology is presented by historical and logical method, statistics and graphic methods, comparative method, correlation regression method, forecasting method, method of theoretical generalization have been used in the article. Dominance and detecting protectionism policy within the process of protecting national markets of goods from international competition have been highlighted and manifestation form of protectionism actions has been defined. Quantitative and qualitative assessment of trade disputes of countries within WTO has been carried out; their subject-object characteristics have been defined; major tools of the most active member countries being a complainant or a respondent have been analyzed. It has been discovered that the largest number of disputes have taken place between the USA and the EU, the USA and China, and China and the EU; methods and tools for trade disputing between the above mentioned countries were identified.

Keywords: international trade, international trade dispute, World Trade Organization, protectionism, trade policy.
\end{abstract}

JEL Codes: F10, F13, F17, F51, F53.

\section{Introduction}

In the current conditions of transformation of trade policy due to the COVID-19 pandemic, disruption of global supply chains, changes in countries' positions in the world market, changing the structure of trade, international division of labour deepening, and increase of international competition force countries to use protectionism measures in order to stabilize national economies. Each country is willing to provide favorable trade conditions simultaneously discriminating its partner. Attempting to obtain better conditions of selling goods and competitive advantages, countries tend to get into trade disputes using various protectionism measures. This problem is of interest because world trade cannot be imagined without accompanying disputes or conflicts among its members but particularly at the time of globalization and growth of international relations value, competition among them acquires special nature.

Copyright (C) 2020. Published by Vytautas Magnus University. This is an open access article distributed under the terms of the Creative Commons Attribution Non-Commercial 4.0 (CC BYNC 4.0) license, which permits unrestricted use, distribution, and reproduction in any medium provided the original author and source are credited. The material cannot be used for commercial purposes. 
The purpose of the article is to study the features, subject-object characteristics and tools for the implementation of modern interstate trade disputes in the context of strengthening protectionist policies and the spread of the COVID-19 crisis The realization of the goal led to the solution of the following tasks of theoretical, methodical and applied nature: to reveal the essence and bases of contradictory situations in international economic relations; systematically describe the features of modern international trade disputes in the context of strengthening protectionist policies and the spread of the COVID-19 crisis.

The object of study is the process of formation and resolution of conflict situations in the system of international economic relations.

The subject of the study is the preconditions, signs, and manifestations, mechanism of settlement and resolution of international trade disputes.

Studying the issues of international disputes appeared to be urgent among leading economists and scientists of the world. This matter has been researched by Rafael Reuveny (Trade and Conflict: Proximity, Country size, and Measures, 2010). Cointegration analysis of the connection between US exports to China and US imports from China has been studied by Wang Wei (A cointegration analysis of the linkage between US exports to China and US imports from China based on vertical specialization). Methods of trade disputes settlement have been systematized by Lukasz Gruszczynski (Science and the Settlement of Trade Disputes in the WTO, 2014) and Robert McDougall (Making Trade Dispute Settlement More Accessible and Inclusive, 2017). Studying protectionism within having trade disputes is observed in the work of Panchenko V. (Hidden protectionism as a challenge to settlement of international economic relations, 2018), the art of trade protection of countries has been outlined by Serpukhov M. (Systematization of trade war tools and hidden protectionism, 2017). Trade disputes within globalization processes have been studied by Shnypko O. (Trade wars within globalization, 2011).

The objective of the article is studying peculiarities, subject-object characteristics and tools of modern intercountry trade disputes realization within the conditions of protectionism policy strengthening.

\section{Methodology}

Methodological basis of this research is an author's approach to analyzing protectionism sources of international trade disputes in international economic relations. It presupposes unified use of a number of well-known general scientific methods as well as a special method that is the method of correlation for studying the state of dependence of world export volumes among countries which are WTO members and a number of registered disputes in World Trade Organization from 1995-2020. Moreover, other special research methods have been used including historical and logical method, statistics and graphic methods, comparative method, correlation regression method, economic mathematic modeling method, forecasting method, method of theoretical generalization when forming the conclusions to the article parts and general conclusions.

\section{Results of research}

\subsection{Concept basis of disputable situations in international economic relations}

Along with the foundation of WTO, a number of intercountry trade disputes have risen with their basis being protectionism methods most frequently. WTO Dispute Settlement Body (further - DSB) and Court of Arbitration are the most efficient institutions of international trade dispute settlement.

International trade is an integral part of international economic relations and may be realized through trade exchange as protectionism means of political and economic pressure of countries. 
In case of one country estimating another country's economic policy as unfavorable and thus taking measures, a trade dispute begins; it leads to a conflict which may grow into a trade war provided that there is no mutual understanding. However, before the relations between two countries aggravate to the point of trade war, they go through a few stages of contradictory trade relations which are similar and acquire a number of inherent features.

According to degree of contradictory relation aggravation in international trade depending on tension between states and possible economic losses, there are (Gordeeva, 2013): 1) a disputable situation in trade; 2) a trade dispute; 3 ) a trade conflict; 4) a trade war (Table 1).

A disputable situation in trade is the beginning of relations aggravation in international trade; however, it is still the most favorable stage for its settlement. Provided that there is no agreement, relations aggravate to the point of a trade dispute. For a dispute to be official it must be manifested with official actions of at least one of member countries, when a country uses trade measures against the will of the other country which is a member of trade connections within WTO, breaches concluded Agreements or leads to country's inexecution of its responsibilities (Tsygankova, 2003). Managing trade disputes is carried out by turning to WTO, fulfilling WTO's decisions or according to decisions of International Commercial Courts of Arbitration.

Table 1. Peculiarities of degrees of disputable relation aggravation in international trade depending on tension between states

\begin{tabular}{|c|c|c|c|}
\hline $\begin{array}{c}\text { Degree of } \\
\text { aggravation }\end{array}$ & $\begin{array}{c}\text { Degree } \\
\text { name }\end{array}$ & Peculiarities & Settlement methods \\
\hline 1 & $\begin{array}{l}\text { Contradictory } \\
\text { situation in } \\
\text { trade }\end{array}$ & $\begin{array}{l}\text { Contradictions and respective tension are inherent. } \\
\text { There are no financial expenses or trade conditions } \\
\text { deterioration on this stage. This is the most favorable } \\
\text { stage to settle relations. }\end{array}$ & $\begin{array}{l}\text { Using international } \\
\text { negotiations and } \\
\text { consultations. }\end{array}$ \\
\hline 2 & Trade dispute & $\begin{array}{l}\text { A term in international law to describe present } \\
\text { tension in relations caused by measures used by one } \\
\text { country in order to aggravate the other's/others' trade } \\
\text { conditions. It is a favorable situation to settle } \\
\text { relations. }\end{array}$ & $\begin{array}{l}\text { Using international } \\
\text { negotiations and } \\
\text { consultations. }\end{array}$ \\
\hline 3 & $\begin{array}{c}\text { Trade } \\
\text { conflict }\end{array}$ & $\begin{array}{l}\text { High tension level in relations with financial } \\
\text { expenses caused by measures used by both sides } \\
\text { towards each other. }\end{array}$ & $\begin{array}{l}\text { Turning to WTO DSB or } \\
\text { to international courts of } \\
\text { arbitration and provided } \\
\text { their decisions are not } \\
\text { fulfilled, corresponding } \\
\text { measures are taken. }\end{array}$ \\
\hline 4 & Trade war & $\begin{array}{l}\text { The highest tension degree which involves using } \\
\text { forbidden intensive measures or ruining trade policy } \\
\text { of a rival country which may lead to major financial } \\
\text { losses of a country against which they were used. }\end{array}$ & $\begin{array}{l}\text { Settlement takes place } \\
\text { by turning to WTO DSB } \\
\text { or to a court of } \\
\text { arbitration. }\end{array}$ \\
\hline
\end{tabular}

Relations between countries acquire disputable state in case when actions of one side create a threat to the other side simultaneously provoking unrest and claims to the first side. A.S. Shevchenko, who studied correlation of dispute and conflict notions in international law, considers that these terms are different arguing that international dispute turning into a conflict depends on contradiction intensifying degree and conflicting acting of sides. Particularly, presence or absence of conflicting behavior of sides presented as active counterwork or armed/non-armed clash define the verges between the notions (Shevchenko, 2012).

The following stage of trade relation aggravation is a trade conflict. Disputable situations turning into conflicts prove low level of political culture, unwillingness or incapability to solve disputes using civilized legal ways which were recorded in Conventions for the Peaceful Settlement of International Conflicts in 1899 and 1907 (Convention for the Peaceful Settlement of International Conflicts). 
The final stage of trade relations aggravation is a trade war. It must be stated that in Practical Dictionary of Humanitarian Law the word war is not used in modern international law any more, it's been substituted with armed conflict (in accordance with United Nations recommendations) (The regulations of United Nations). Trade armed conflict may lead to severe consequences such as transnational terrorism, organized international crime etc. Researching subjects and objects of trade disputes is of interest. Thus, subjects of international trade disputes are considered to be sides of international trade relations that is one or both sides that act in a way that obstructs bilateral trade. Among subjects there are countries which may be both WTO members and those which are not organization's members, companies, integration groups or international organizations. Third parties that are involved in conflicting relations at any phase and aim at their settling are called participants.

Object of international trade disputes is some trade relations due to which the sides' interests are incompatible and a situation cannot satisfy both sides simultaneously. As a rule, an international trade dispute arises as a result of one side using measures of domestic or external economic policy that discriminate the other subject within a particular industry. Among objects there are tariff, non-tariff or combined measures of external trade policy; tools of domestic economic policy which discriminate foreign producers; export goods production of a particular industry of a country; export and import of goods and services of a specific country; joint national export of a country.

Overall, grounds of rise of trade misunderstanding include tariff regulations and raw material resources; discriminating and limiting measures towards import; tax regimes for imported goods and products; antidumping measures and subsidizing; dictating own standards; compensatory measures aimed against particular goods groups; illegal export (smuggling, counterfeit consumer goods); sanitary and phyto-sanitary measures; breaking the rule of major assistance regime; breaking a law of intellectual property and rights for intellectual property objects etc.

In order to understand essence and reasons of trade disputes appearance more profoundly, it's worth to study theoretical research on international trade disputes determinants which define specific features of international trade disputes character which may further be used as classification criteria (WTO, 2019; Uskova, 2019; Yatsenko, 2019; Reznikova, 2016) (Table 2).

\section{Table 2. Key determinants of international trade disputes and their classification}

\begin{tabular}{|l|l|}
\hline \multicolumn{1}{|c|}{ Determinants } & \multicolumn{1}{c|}{ Meaning and peculiarities } \\
\hline $\begin{array}{l}\text { zoloConflicts of external trade } \\
\text { interests of countries }\end{array}$ & Protectionism, political, ideological, ecological, economic, and social reasons. \\
\hline National reasons & $\begin{array}{l}\text { Supporting domestic producers, protecting own interests, new markets } \\
\text { expansion, annihilation of competitors. }\end{array}$ \\
\hline Situation aggravation stages & Disputable situation in trade, trade dispute, trade conflict, and trade war. \\
\hline Subjects & Countries, companies, integration groups, international organizations. \\
\hline $\begin{array}{l}\text { Objects (measures of domestic } \\
\text { and external economic policy of } \\
\text { one side that discriminate a trade } \\
\text { partner; economy area of the other } \\
\text { side which bears economic losses) }\end{array}$ & $\begin{array}{l}\text { - tariff, non-tariff or combined measures of external trade policy; } \\
\text { - tools of domestic economic policy that discriminate foreign producers; }\end{array}$ \\
\hline - - joint national export of a country. \\
\hline Duration & $\begin{array}{l}\text { Local, subregional, regional, transcontinental, global. } \\
\text { (overt 15 months). }\end{array}$ \\
\hline Settlement methods & $\begin{array}{l}\text { Negotiations, consultations, mediation, international court, international } \\
\text { arbitration, mechanisms of regional international organizations, mechanisms of } \\
\text { global international organizations (WTO DSB, UN). }\end{array}$ \\
\hline Consequences/results & $\begin{array}{l}\text { Political, ideological, organizational, ecological, economic, social, } \\
\text { technological. }\end{array}$ \\
\hline
\end{tabular}

Considering experts statement, during the time of transformation of state policy of protecting national markets (of goods, services, and objects of intellectual property) from foreign 
competition, protectionism has turned from basic protection of tariff (and later non-tariff) limits implementation into a complicated state mechanism of increasing competitiveness of national economy that is defined as neo-protectionism (Reznikova, 2016). The latter includes untraditional ways of undesirable goods import limitation; prevalence of attacking nature with aggressive expansion features; emerging of collective protectionism on macro level of modern integration unions; widening of tools number at the expense of using relatively new ones, those which are more difficult to regulate internationally (Dovgal, 2002).

The WTO has recorded about 400 notifications of changes in trade policy in the context of the COVID-19 pandemic: more than 250 notifications restricted international trade, the rest - directed trade. Against the background of active outbreak of the COVID-19 pandemic in early 2020, governments are actively implementing trade measures that suddenly change international supply chains [Zhu, 2020]. About two-thirds of the notifications from WTO members in response to trade protection measures under pandemic implemented Sanitary and Phytosanitary Measures and Technical Barriers to Trade. Other notifications are in accordance with the Agreement on the Carriage of Goods, the Agreement on Trade-Related Aspects of Intellectual Property Rights, the Agreement on Public Procurement, the Agreement on Market Access, the Agreement on Trade Facilitation and Quantitative Restrictions Agreement (WTO, 2020).

Since there is no country which wouldn't use protectionism tools as state policy to protect national market from foreign competition, it is recognized that each national economy has some extent of grounded protectionism that is optimal amount of limits in trade. "Grounded protectionism" is considered to be such a level of national economies protection which doesn't oppose national interests and doesn't complicate foreign goods access to the market. It is considered that neo-protectionism is a factor of economy competitiveness increase which tends to set administrative, financial, credit, technical, and other barriers which considerably complicate free movement of goods across countries' borders (Kelichavy, 2014). Complications include tools of hidden protectionism such as fiscal and tariff barriers, export quotas, technical barriers, export subsidies, labeling standards, phyto-sanitary standards and requirements, state support, currency policy, etc. For instance, refusing giving privileges according to general system of preferences which were used by South Korea, Singapore, Taiwan, and Hong-Kong, the USA has gotten "voluntary" restriction of export to developed countries and of rebuilding its competitive positions on the international market from the countries mentioned above (Raišienè, 2019). Therefore, neoprotectionism's goal is to eliminate inner contradictions of economic liberalism which lie in its bilaterality: on the one hand, economy openness and state laissez-faire, on the other hand, domestic producer protection. Official WTO data study of causes and implementation of protectionism and neo-protectionism methods of trade dispute by leading world countries is presented in Table 3 and it gives ground to define motives in each confrontation between particular countries or regions (Yatsenko and Uskova, 2019; Panchenko and Reznikova, 2016).

Table 3. Top three participants of trade disputes and their tools

\begin{tabular}{|c|l|}
\hline Participants & \multicolumn{1}{c|}{ Tools } \\
\hline The USA - the EU & $\begin{array}{l}\text { Hidden protectionism; Dictating own standards; Misuse of WTO approved antidumping } \\
\text { measures; Violating the rule of major assistance regime }\end{array}$ \\
\hline The USA - China & $\begin{array}{l}\text { Export restrictions; Illegal export (smuggling, counterfeit consumer goods); Artificial } \\
\text { Yuan inflation }\end{array}$ \\
\hline China - the EU & $\begin{array}{l}\text { Dictating own standards; Manipulating export tariffs; Sanitary and phyto-sanitary } \\
\text { measures }\end{array}$ \\
\hline
\end{tabular}

It's natural that powerful countries use much more ways to reach their goals than those countries which belong to lower rank in the informal international political hierarchy. 


\subsection{Modern international trade disputes}

There have been a lot of trade disputes throughout the international trade history. Only over the last 25 years, as long as WTO has existed, from 1995 to 2020 the organization has considered 597 disputes from member countries. They have different participation experience in such disputes, as complaining country and responding country. Quantity information on WTO countries which took part in trade disputes from 1995-2020 most frequently is presented in Table 4.

Table 4. Top 10 countries participating in international trade disputes within WTO, 1995-2020

\begin{tabular}{|c|c|c|c|c|c|}
\hline Rating & Complaining country & $\begin{array}{c}\text { Number of } \\
\text { times }\end{array}$ & Rating & Defending country & $\begin{array}{c}\text { Number of } \\
\text { times }\end{array}$ \\
\hline 1 & The USA & 124 & 1 & The USA & 156 \\
\hline 2 & The EU & 104 & 2 & The EU & 87 \\
\hline 3 & Canada & 40 & 3 & China & 44 \\
\hline 4 & Brazil & 33 & 4 & India & 32 \\
\hline 5 & Japan & 26 & 5 & Canada & 22 \\
\hline 6 & Mexico & 25 & 6 & Argentina & 22 \\
\hline 7 & India & 24 & 7 & South Korea & 19 \\
\hline 8 & Argentina & 21 & 8 & Brazil & 17 \\
\hline 9 & China & 21 & 9 & Japan & 16 \\
\hline 10 & South Korea & 21 & 10 & Mexico & 15 \\
\hline
\end{tabular}

Source: built by authors upon (WTO, 2020)

The most frequent participant of international trade disputes is the USA with total number of 280 cases (124 times as a complainant and 156 as a respondent). Following the USA in the rating of the biggest number of disputes there is the EU with 104 and 87 cases accordingly. China as a promptly developing country in international trade is often a respondent ( 21 times) rather than a complainant (44 times). The biggest number of disputes took place between the USA and the EU, the USA and China. Such conflicts have been defined as transatlantic. Exploring subject characteristics of existing disputes, there's a tendency observed that Indonesia may enter this list in a few years' time; at present the country has 23 trade disputes within WTO - 13 times as a complainant and 10 times as a respondent.

The number of disputes with mutual countries' complaints which appealed to WTO most frequently during 1995-2020 is presented in Table 5.

Table 5. Quantity characteristics of mutual complaints of WTO member countries, 1995-2020

\begin{tabular}{|c|c|c|c|c|c|c|c|c|c|c|}
\hline Complainant & 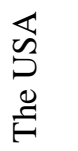 & 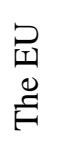 & $\underset{\widetilde{\pi}}{\overparen{\pi}}$ & : & 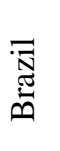 & $\cdot \frac{8}{e_{i}}$ & 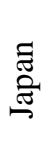 & 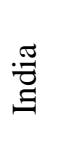 & 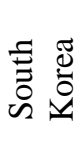 & 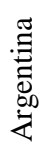 \\
\hline The USA & $\mathrm{x}$ & 20 & 8 & 23 & 4 & 7 & 6 & 8 & 6 & 5 \\
\hline The EU & 35 & $\mathrm{x}$ & 6 & 9 & 5 & 3 & 6 & 11 & 4 & 8 \\
\hline Canada & 20 & 9 & $\mathrm{X}$ & 4 & 1 & - & 1 & 1 & 2 & - \\
\hline China & 17 & 5 & 1 & $\mathrm{x}$ & - & - & - & - & - & - \\
\hline Brazil & 11 & 7 & 4 & 1 & $\mathrm{X}$ & 1 & - & 1 & - & 2 \\
\hline Mexico & 10 & 3 & - & 4 & - & $\mathrm{x}$ & - & - & - & 1 \\
\hline Japan & 8 & 1 & 2 & 2 & 2 & - & $\mathrm{X}$ & 2 & 4 & 1 \\
\hline India & 11 & 7 & - & - & 1 & - & - & $\mathrm{x}$ & - & 1 \\
\hline South Korea & 14 & 3 & - & - & - & - & 3 & - & $\mathrm{x}$ & - \\
\hline Argentina & 5 & 6 & - & - & 1 & - & - & - & - & $\mathrm{x}$ \\
\hline
\end{tabular}

The largest number of mutual complaints is noticed between the USA and the EU. Bilateral goods trade volume between them in 2018 reached $€ 673.7$ billion which is about $17 \%$ of general structure of the foreign trade of the EU (Eurostat Statistics, 2018). The USA is also the largest 
EU's partner in international services trade. The countries are the largest trade partners in the world. Considerable trade volumes between the countries are in machinery construction and high technologies industries, pharmaceutical products and cars as well as optical and photo-medical equipment. EU - USA trading is concentrated in employment and capital-intensive sectors which are featured with scale effect and inside industry trade. These days the biggest number of disputes arises in consumption and food safety spheres, environment protection, and subsidizing.

Studying the subject-object characteristics over the time of WTO existence, the biggest number of disputes over goods is observed in agricultural products and metallurgical industry (aluminium and steel goods) trading; they are followed by semi-manufactured goods, textile products, cars, means of transport, and their technical equipment, sugar, aircrafts, alcoholic drinks, saw timber, poultry, and shrimp. According to WTO report, the largest number of disputes over services was started in logistics, finance, and general social and cultural services. Among the objects of intellectual property there are patenting, author's and allied rights violation, and trademarks.

Vivid examples of retrospective analysis are a textile dispute between Japan and the USA which lasted for over 20 years, during the time the dispute has gone through all the stages reaching trade conflict; a trade conflict between the EU and the USA on prices and tariffs for bananas supply from Africa and Latin America finished after 8 years of considering the case. Baltic countries imposed an embargo on agricultural products from Belorussia at the end of the 1980s as a result of Chernobyl disaster; in 2003 Germany imposed an embargo on bringing beef from Great Britain due to "mad cow disease" epidemic and despite the fact that in 2006 the EU annulled the ban on meat from Great Britain, Germany continued keeping to its views (Gordeeva, 2013).

The case of the most global international trade dispute in the $21^{\text {st }}$ century between the USA and China which concerns interests of many countries of the world is of special interest. 20182019 were marked with a new wave of protectionism in international trade. The American government introduced $25 \%$ duty on steel products import and $10 \%$ import duty on aluminium products from March 8, 2018 (America's Trade Laws, 2019), the decision was made by USA President Donald Trump as recommended by USA Trade Secretary (Isakhanova and Kryvetska, 2018). The President highlighted that other countries fill the USA with a huge amount of steel which leads to a crisis in American steel industry. The news from the USA has already led to share price decrease in Asia: Japanese Nikkei 225 index lost over 2\%; Japanese car manufacturing giant Toyota's shares lost over 2\%; Nippon Steel shares have declined by over 4\% (BBC News, 2018).

Ten largest countries that export steel to the USA include Canada, Brazil, South Korea, Mexico, Russia, Turkey, Japan, Germany, Taiwan, and of course China. Products imported from these countries comprise $77 \%$ of all USA steel import totally. The listed countries responded with a joint lawsuit to WTO for appointing consultations on the issue as the USA "challenged" the whole world. In response, China officially initiated trade dispute against the USA in WTO (DS544) (WTO, 2017). China is convinced that USA's measures are nothing but intentional, using them is recorded in regulations of WTO Agreement on intentional measures. Such countries as India, Canada, Russia, the European Union and Singapore made an inquiry to join the consultations as third parties as of April, 2018. Japan and Russia were decisive and informed the WTO Council on Products Trading that they reserved for them the right to use countermeasures against the USA according to article 8.2 of WTO Safeguards Agreement.

Political conjuncture of trade relations between the Administration of Xi Jinping and the Administration of Donald Trump is complicated by the fact that over the last two years the countries have initiated a big number of lawsuits to WTO which concerned not only a dispute around aluminium and steel but around imported consumer goods of both countries. It must be mentioned that Chinese government has implemented limiting measures in reply, particularly additional import duties for main goods groups that are exported from the USA to China accounting for 128 positions: $25 \%$ for pork and aluminium scrap metal, $15 \%$ for wine, steel pipe 
products used in oil/gas sphere as well as different kinds of fruits and nuts including apples, walnut, and grapes (WTO Report on G20 Trade Measures, 2019). USA export goods to China which undergo the listed above additional measures account for $\$ 3$ billion. As a result of these deeds the USA brought an action to WTO (DS558) (WTO, 2018). Sharing the opinion of experts, such trade policy of the USA has become an opportunity for China to use legal protectionism measures according to the WTO right so that significant export oriented sectors of the USA inflicted losses.

Washington requested a consultation concerning measures on protecting intellectual property rights (DS542) (WTO, 2018) and introduced new duties on even bigger number of Chinese goods whose annual import volume accounts for around $\$ 34$ billion. These duties cover 818 goods positions including plane construction parts, cars, hard disks, intellectual property objects, etc. The duties grew due to no progress in trade negotiations between Washington and Beijing as Donald Trump informed, as well as because of "unfair trade practices" on Chinese side, particularly theft of intellectual property (Korenovskaya, 2018). Shortly after these events China initiated more disputes against the USA in WTO. Trade disputes concerned limiting measures on Chinese import industrial goods to the USA (3 lawsuits including DS543 (WTO, 2018); DS565 (WTO, 2018); DS587 (WTO, 2019)), photoelectric devices made of monocrystalline silicon (DS562 (WTO, 2018)), renewable energy goods (DS563 (WTO, 2018)).

Protectionism measures of Washington caused supply exceeding demand in the EU and thus decrease of prices for these goods. Moreover, steel and alumunium produce which was made in the EU and was supposed to be exported to the USA, stayed on the domestic market which led to production surplus. The EU initiated special investigation concerning particular kinds of steel produce. The list includes about 300 goods which cover nearly whole assortment of rolled metal and pipes. The proceedings finished with introducing protecting duties and quotas in order to protect European producers from exorbitant import (European Commission, 2018).

There is an opinion that the American President ignores the rules of international trade system developed by WTO and which are common for all countries. But the Government reckons that it doesn't break WTO rules referring to article 21 of the General Agreement on Trade and Tariffs which presupposes an opportunity to implement trade limits considering national security protection. However, the majority of experts and political figures assume that the American President considers duties introduction to be a measure of pressing large trade partners of the USA in order to force them to make concessions (Martin, 2018).

In December 2019 representatives of both countries arrived at agreement about ceasing bilateral trade limits coming to a conclusion about "the first phase" of bilateral agreement according to which China is obliged to additionally purchase American goods at $\$ 80$ billion over the next two years' time. The agreement covers intellectual property, technologies, agriculture, and financial services. The USA, for its part, retains $25 \%$ duties on Chinese goods but duty tariffs on other imported positions are promised to be reduced to 7.5\% (Reuters, 2020).

Agreeing with experts' estimation, continuing the trade dispute between Washington and Beijing may decrease world economy growth in 2020, reduce world trade volume, cause a decline of the world GDP and a crisis of financial market (Uskova, 2019). Consequences of these and other trade disputes undermine not only national economies but the world economy as well, they considerably decrease people's welfare level around the world.

Further possible risk of trade disputes rise appears due to the fact that WTO members will increasingly misuse exceptions considering security in order to justify trade limits. Roberto Azevêdo (2019) stated that national security is not a matter which may be settled by disputing, countries should settle their national security issues on political level rather than test WTO system boundaries.

Using correlation-regressive method for studying dependence state of the world export volumes between WTO member countries and the number of registered disputes within the organization during 1995-2019, justifies that there is a particular correlation between these indices. Correlation coefficient accounts for -0.56 which proves negative interdependence. 


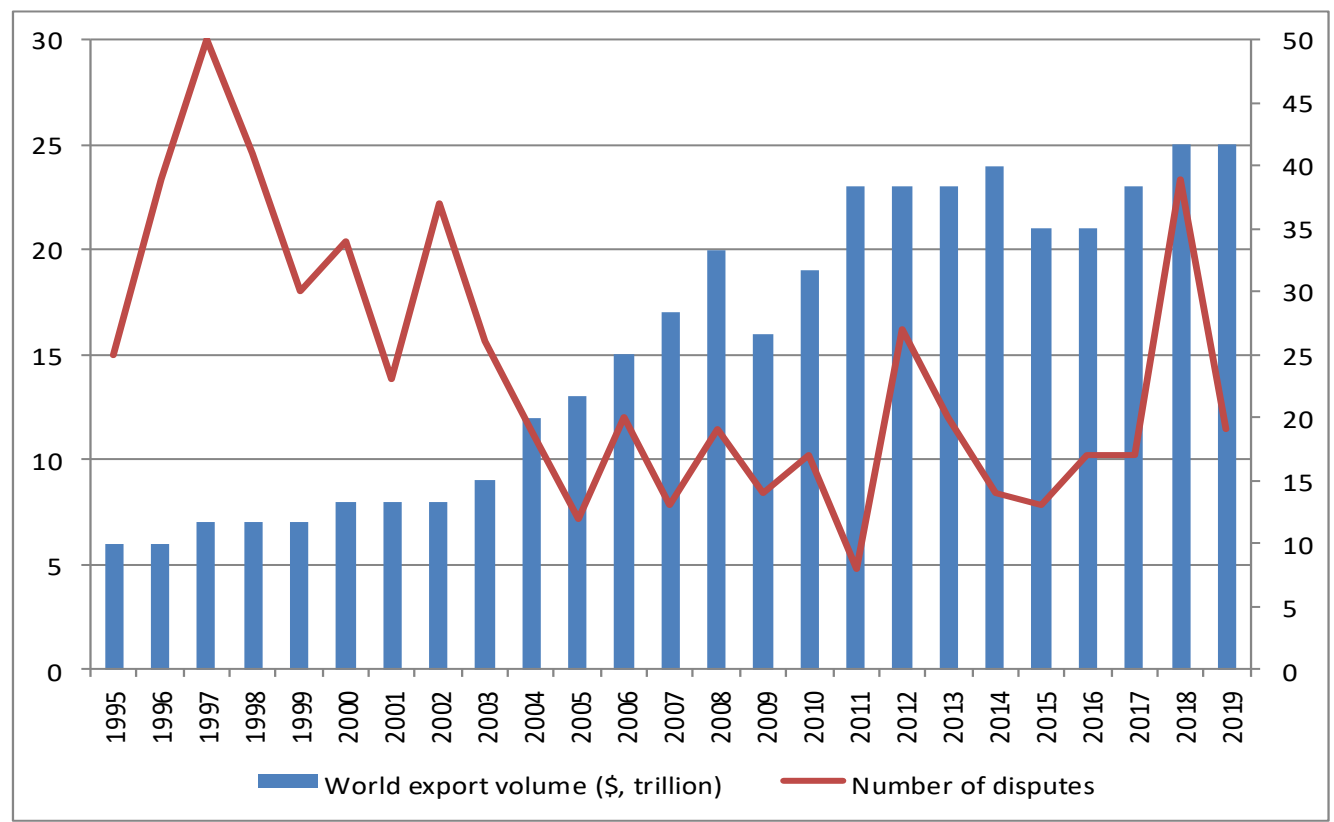

Figure 1. Dynamics of world export volumes and a number of international trade disputes within WTO, 1995-2019

Source: built by authors in Microsoft Excel

Summing up the research, it is reasonable to forecast trade disputes up until 2023 using the lineal method of trend forecasting (Fig. 2).

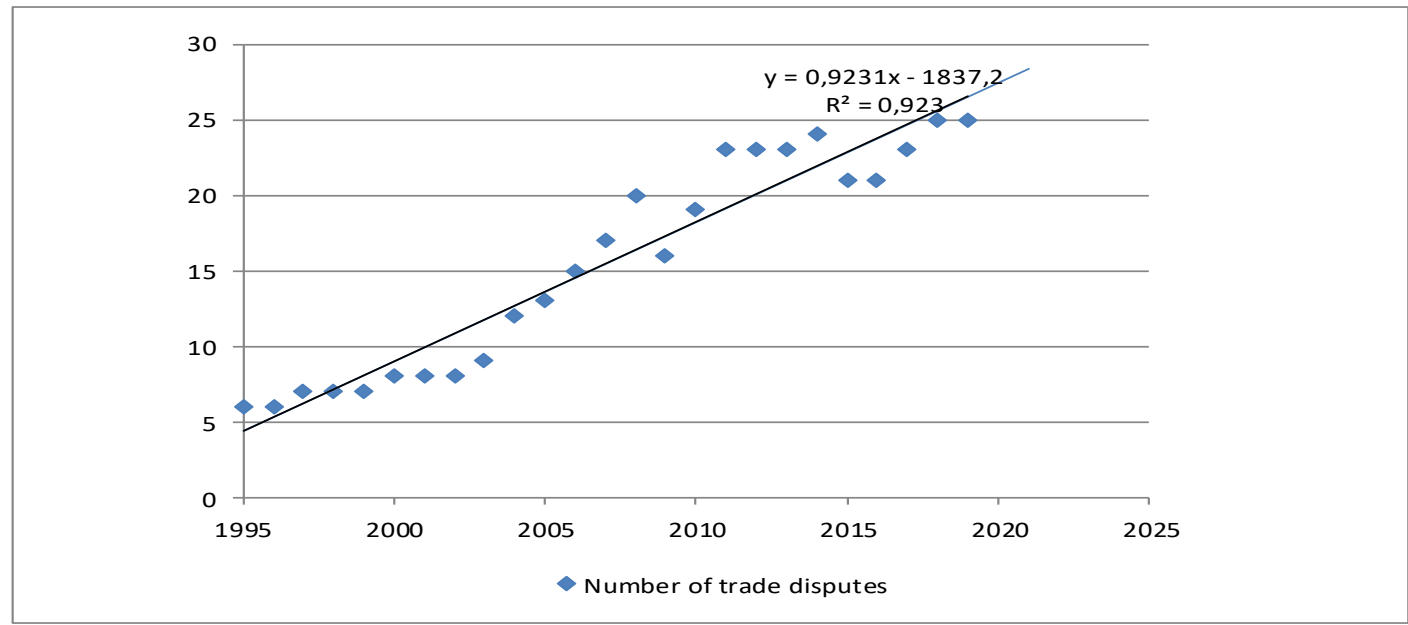

Figure 2. The line of international trade disputes increase with their further forecast, 1995-2023

Source: built by authors in Microsoft Excel

In Figure 2 we can see that a number of international trade disputes tends to increase in the following years and the lineal dependence $\mathrm{R}^{2}=0,923$ proves the reliability of the forecast.

Modern realities lead up the subjects of international trade relations to a blind alley. Over the time of quarantine all over the world as a result of rapid spread of COVID-19, most representatives of international trade suffer losses (WTO, 2020). Chinese export and import volumes have considerably decreased at the beginning of 2020 which affected major trade partners of the country that significantly depend on Chinese production. American exporters have lost $80 \%$ of their goods 
supplies on the borders of countries due to trade supply suspension as a result of customs borders shutting (Reuters, 2020). European countries' governments enveloped in pandemic are forced to appeal to protectionism measures. Coronavirus outbreak caused huge irregularities in global chains of supply and enterprises' economic activity among countries.

Despite some relations improvement between the USA and China at the end of last year, American government impairs set economic relations between the countries calling COVID-19 "Chinese Coronavirus" highlighting its origin. The returned feeling of tensed relations between the USA and China stands in the way to cooperate as it was during the financial crisis in 2008. Pandemic outbreak provokes anxiety of multinational American corporations concerning supply chains based in China.

Economic influence of COVID-19 is expected to be long-lasting and dramatic and to cause new trade disputes in international economic relations sphere and globalization processes in general. Governments all over the world have introduced extreme measures to support their healthcare systems and to protect national economies' decrease.

\section{Conclusions}

Based on theoretical generalization of trade conflicts escalation in international economic relations, the following conclusions of theoretical, methodical, and practical scientific nature according to the set goal have been formulated:

1. Four stages of disputable relations in international trade depending on the tension between the countries have been systematized: disputable situation in trade, trade dispute, trade conflict, and trade war; peculiarities of modern trade disputes and their determinants (conflicts of external economic interests of countries, national reasons, degrees of disputable situation aggravation, subjects, objects, scales, duration, regulation methods and consequences) have been systematized as well. It has been proved that trade disputes have protectionism origin. The essence and conceptual basics of protectionism policy in international trade disputes have been discovered based on the example of world leading countries: between the USA and the EU, the USA and China, and China and the EU, which use methods of hidden protectionism, illegal export, artificial currency inflation, dictating own standards, etc.

2. Quantity and quality transformations of international trade disputes during WTO existence from 1995-2020 have been comprehensively and systematically characterized, their total number accounts for 597 disputes. Ten most active driving countries (including the USA, the EU, Canada, China, Brazil, Mexico, Japan, India, South Korea, and Argentina) have been identified. Their subject-object features have been defined; disputes over produce of agriculture and metallurgical industry, semi-manufactured goods, textile products, cars and other means of transport appear most frequently. The most resonant international trade conflict of modern times between the USA and China has been characterized; its features and consequences have been identified. Economic and trade consequences of COVID-19 pandemic outbreak have been analyzed.

\section{References}

Convention for the Peaceful Settlement of International Conflicts (I Hague Convention). (1907). Verkhovna Rada of Ukraine. - https://zakon.rada.gov.ua/laws/show/995_938\#Text [2019 11 20]

Dovgal, O. (2002). Economic protectionism: an analysis of world experience. // Journal of the Kharkov national university named after V. N. Karazin. Economic series. Vol.564: 220-222. 
European Commission. (2018). EU adopts rebalancing measures in reaction to US steel and aluminium tariffs. -https://ec.europa.eu/commission/presscorner/detail/en/IP_18_4220 [2019 11 20]

Eurostat Statistics Explained. (2018). USA-EU - international trade in goods statistics. https://ec.europa.eu/eurostat/statistics-explained/index.php/USA-EU_-international_trade_in_goods_statistics [2019 $1120]$

Gordeeva, T. (2013). International trade disputes in the current regulatory paradigm // International economic policy. Vol.2. No.19: 110-111.

Gu H., Westbrook T. (2020). Phase 1 commodity targets likely more than China can chew: analysts. Reuters. Business news. - https://www.reuters.com/article/us-usa-trade-china/phase-1-commodity-targets-likely-more-thanchina-can-chew-analysts-idUSKBN1ZD1K2 [2020 01 14].

Irwin D. (1995) The GATT in Historical Perspective. American Economic Review. Vol.85. No.2: 323-328.

Isakhanova, N., Kryvetska O. (2018). US trade restrictions against imports steel and aluminum: the reaction of the world. // All-Ukrainian weekly legal publication «Legal Law Online». Vol.21-22: 623-624.

Kelichavy, A. (2014). The politics of protectionism as a factor of increase competitiveness of the economy. An efficient economy. Vol. 6, pp. 88-94.

Korenovskaya, S. China has declared the start of the largest trade war. DW Made for minds. https://p.dw.com/p/30v4i [2019 11 20].

Martin N. Trump Against All: When Will Trade Conflict Turn into a Trade War? DW Made for minds. https://p.dw.com/p/30vj3 [2019 11 20].

Panchenko, V., Reznikova N. (2016). Neo-protectionism as a tool for eliminating the internal contradictions of liberalism. // Journal of the Dnieper State Agrarian and Economic University "Effective Economy». Vol.1: 158183.

Raišienė, A., Yatsenko, O., Nitsenko, V., Karasova, N., Vojtovicova, A. (2019). Global dominants of Chinese trade policy development: Opportunities and threats for cooperation with Ukraine. // Journal of International Studies. Vol.12. No.1: 193-207. - https://doi.org/10.14254/2071-8330.2019/12-1/13

Serpukhov, M. (2013). Hidden protectionism as an instrument of modern international trade policy. // Economics of development. Vol.4. No68: 23-27.

Shevchenko, A. (2012). International dispute, its legal nature and peaceful settlement through arbitration. // Foreign Trade: Economics, Finance, Law. Vol.5: 142-144.

Tsygankova, T. (2003). Global trading system: development of WTO institutions, rules, instruments: monograph. - Kyiv: KNEU educational and methodical center. $410-411 \mathrm{pp}$.

US steel and aluminium imports face big tariffs, Trump says. (2018). BBC News. https://www.bbc.com/news/world-us-canada-43249614 [2019 11 17].

What You Need To Know: Section 232 Investigations and Tariffs. (2018). WhiteHouse.gov https://www.whitehouse.gov/briefings-statements/need-know-section-232-investigations-tariffs/ [2019 1121$].$

World Trade Organization. (2019). Report on G20 Trade Measures. - https://www.wto.org > english > news_e > news19_e [2019 10 20]

World Trade Organization. (2020). Chronological list of disputes cases 1995-2020. https://www.wto.org/english/tratop_e/dispu_e/dispu_status_e.htm [2020 12 04]

World Trade Organization. (2020). How COVID-19 is changing the world: a statistical perspective. Volume II. - https://www.wto.org/english/tratop_e/covid19_e/ccsa_publication_e.pdf [2020 12 04]

World Trade Organization. (2020). WTO members' notifications on COVID-19 https://www.wto.org/english/tratop_e/covid19_e/notifications_e.htm [2020 12 04]

Yatsenko, O., Uskova D. (2019). Modern determinants and forms of international trade disputes. // Journal of Uzhgorod National University. International Economic Relations. World Economy Series. Vol.28, No.2.: 173-176.

Zhu M. (2020). COVID-19's impact on international trade contracts // China Business Law Journal. https://law.asia/covid-19-trade-contracts-impact/ [2020 1014 14] 